\title{
Re-Emergent Inhibition of Cochlear Inner Hair Cells in a Mouse Model of Hearing Loss
}

\author{
Stephen Paul Zachary ${ }^{1,3,4}$ and $\odot$ Paul Albert Fuchs ${ }^{1,2,3,4}$ \\ ${ }^{1}$ Solomon H. Snyder Department of Neuroscience, ${ }^{2}$ Department of Otolaryngology, and Centers for ${ }^{3}$ Sensory Biology and ${ }^{4}$ Hearing and Balance, Johns \\ Hopkins School of Medicine, Baltimore, Maryland 21205
}

Hearing loss among the elderly correlates with diminished social, mental, and physical health. Age-related cochlear cell death does occur, but growing anatomical evidence suggests that synaptic rearrangements on sensory hair cells also contribute to auditory functional decline. Here we present voltage-clamp recordings from inner hair cells of the C57BL/6J mouse model of age-related hearing loss, which reveal that cholinergic synaptic inputs re-emerge during aging. These efferents are functionally inhibitory, using the same ionic mechanisms as do efferent contacts present transiently before the developmental onset of hearing. The strength of efferent inhibition of inner hair cells increases with hearing threshold elevation. These data indicate that the aged cochlea regains features of the developing cochlea and that efferent inhibition of the primary receptors of the auditory system re-emerges with hearing impairment.

Key words: age-related hearing loss; cholinergic inhibition; cochlea; inner hair cell; olivocochlear system; synaptic transmission

\section{Significance Statement}

Synaptic changes in the auditory periphery are increasingly recognized as important factors in hearing loss. To date, anatomical work has described the loss of afferent contacts from cochlear hair cells. However, relatively little is known about the efferent innervation of the cochlea during hearing loss. We performed intracellular recordings from mouse inner hair cells across the lifespan and show that efferent innervation of inner hair cells arises in parallel with the loss of afferent contacts and elevated hearing threshold during aging. These efferent neurons inhibit inner hair cells, raising the possibility that they play a role in the progression of age-related hearing loss.

\section{Introduction}

Despite the fact that age-related hearing loss (ARHL) is a common sensory deficit, very little is known about the physiology of aged cochlear hair cells. The adult cochlear epithelium is difficult to extract and survives poorly once removed from the dense surrounding bone, and these technical issues are magnified when dealing with aged tissue. Nonetheless, a mechanistic understanding of ARHL requires a physiological characterization of aged hair cells to complement the extensive body of anatomical work already performed. To this end, we have examined efferent synaptic inputs onto inner hair cells (IHCs) of the C57BL/6J (C57) mouse cochlea across the lifespan.

\footnotetext{
Received March 6, 2015; revised May 18, 2015; accepted May 27, 2015.

Author contributions: S.P.Z. and P.A.F. designed research; S.P.Z. performed research; S.P.Z. analyzed data; S.P.Z. and P.A.F. wrote the paper.

This work was supported by National Institute on Deafness and Other Communication Disorders Grants R01 DC001508, T32 DC000023, P30 DC005211, and F31 DC014184. We thank E. Glowatzki, R. Fettiplace, and A. Lauer for advice and assistance.

The authors declare no competing financial interests.

Correspondence should be addressed to Paul Albert Fuchs, 720 Rutland Avenue, Ross 820, Baltimore, MD 21205. E-mail: pfuchs1@jhmi.edu.

DOI:10.1523/JNEUROSCI.0879-15.2015

Copyright $\odot 2015$ the authors $\quad 0270-6474 / 15 / 359701-06 \$ 15.00 / 0$
}

During the first 2 postnatal weeks, immature IHCs receive cholinergic efferent input and express $\alpha 9 / 10$-containing nicotinic acetylcholine receptors (nAChRs; Elgoyhen et al., 1994; Glowatzki and Fuchs, 2000; Morley and Simmons, 2002; Roux et al., 2011). Calcium influx through these nAChRs gates associated small-conductance, calcium-activated potassium (SK) channels, rendering these synapses inhibitory (Glowatzki and Fuchs, 2000). The function of efferent innervation of immature IHCs is uncertain, but it is thought that efferent inhibition patterns the activity of the developing auditory pathway (Johnson et al., 2011) and plays a role in establishing central tonotopy (Clause et al., 2014; Sendin et al., 2014). After P14, IHCs lose their efferent contacts, nAChRs, and SK channels and are no longer responsive to ACh (Simmons, 2002; Katz et al., 2004). Although healthy adult IHCs lack efferent innervation, these contacts appear to return to IHCs in the damaged cochlea as seen in electron micrographs of the adult guinea pig after AMPA-induced excitotoxicity (Ruel et al., 2007) and in the 1-year-old C57 mouse (Lauer et al., 2012), considered an animal model of ARHL. Thus, we performed wholecell patch-clamp recordings on young, adult, and elderly C57 IHCs in the apical portion of the cochlea to deter- 
mine whether presumptive efferent synapses were indeed functional.

\section{Materials and Methods}

Animals. Female C57 (P7-P16) mice were used for this study. Mice older than 7 months of age were retired breeders acquired from The Jackson Laboratory. All procedures involving animals were approved by the Johns Hopkins Animal Care and Use Committee.

Electrophysiology. Each recorded cell was from an individual animal. Mice were anesthetized deeply with isoflurane and decapitated, and the temporal bone was removed. For dissections, standard extracellular solution (see below) was modified to contain $0.5 \mathrm{mM} \mathrm{CaCl}_{2}$ and $1.7 \mathrm{~mm}$ $\mathrm{MgCl}_{2}$. An apical region of the cochlear sensory epithelium was excised, pinned to a coverslip, and then placed in a recording chamber on the microscope stage in which it was perfused continuously with saline at room temperature. Recording pipettes had resistances of 3-6 M $\Omega$. Series resistance was $<15 \mathrm{M} \Omega$ and not compensated. Recordings were made in a standard external solution containing the following (in mM): $5.8 \mathrm{KCl}$, $144 \mathrm{NaCl}, 1.3 \mathrm{CaCl}_{2}, 0.9 \mathrm{MgCl}_{2}, 0.7 \mathrm{NaH}_{2} \mathrm{PO}_{4}, 5.6$ glucose, and 10 HEPES, pH 7.4. In some experiments, an increase in $\mathrm{KCl}$ was offset by a decrease in $\mathrm{NaCl}$. Standard intracellular solution contained the following (in mM): $135 \mathrm{KCl}, 0.1 \mathrm{CaCl}_{2}, 3.5 \mathrm{MgCl}_{2}, 5 \mathrm{EGTA}, 4 \mathrm{HEPES}$, and 2.5 Na-ATP, pH 7.2. Junction potential was not offset using this internal solution. To set $E_{\mathrm{Cl}}$ at $-132 \mathrm{mV}$, the following internal solution was used (in mM): 140 Cs-methanesulfonate, $0.7 \mathrm{MgCl}_{2}, 0.1 \mathrm{CaCl}_{2}, 5$ HEPES, 5 EGTA, and 2.5 Na-ATP, pH 7.2. To set $E_{\mathrm{Cl}}$ at $-80 \mathrm{mV}$, the following internal solution was used (in $\mathrm{mM}$ ): $140 \mathrm{Cs}$-methanesulfonate, $2.6 \mathrm{KCl}$, $3.5 \mathrm{MgCl}_{2}, 0.1 \mathrm{CaCl}_{2}, 5$ HEPES, 5 EGTA, and $2.5 \mathrm{Na}-\mathrm{ATP}, \mathrm{pH}$ 7.2. Cs-based internals had a corrected junction potential of $-10 \mathrm{mV}$. Recordings were made on an Axioskop2 (Zeiss) microscope with differential interference contrast and a $40 \times$ water-immersion objective. Multiclamp 700B (Molecular Devices), pClamp 10 (Molecular Devices), and a Digidata 1440A (Molecular Devices) were used for data collection.

Data were analyzed in Clampfit (Molecular Devices), MiniAnalysis (Synaptosoft), Prism (GraphPad), and Excel (Microsoft). Fisher's exact test (two-sided) was used to compare proportions of innervated IHCs (Fig. 1B). Unpaired $t$ test with Welch's correction (two-sided) was used for the data shown in Figures $1 C$ and $3 C$. Cells were classified as lacking efferent innervation if they remained viable in $40 \mathrm{~mm}$ external $\mathrm{K}$ for $5 \mathrm{~min}$ without synaptic activity.

Immunohistochemistry and imaging. Cochleae were dissected out of the temporal bone and perfused through the round window with $4 \%$ paraformaldehyde in PBS. Cochleae were fixed for $30 \mathrm{~min}$ at room temperature and then rinsed with PBS. Cochlear epithelia were permeabilized with $0.5 \%$ Triton $\mathrm{X}-100$ for $30 \mathrm{~min}$ at room temperature and then blocked for $1.5 \mathrm{~h}$ in $4 \%$ bovine serum albumin (BSA). Incubation with primary antibodies (1:200) in $2.5 \%$ BSA occurred overnight at $4^{\circ} \mathrm{C}$. After thorough washing, incubation with secondary antibodies (1: 1500 ) in 3\% BSA occurred for $1 \mathrm{~h}$ at room temperature. After additional washing in PBS, the tissue was mounted on slides using FluorSave mounting medium.

Confocal micrographs were acquired with a Zeiss LSM-700 microscope. Analysis was not blinded and was performed in Imaris (Bitplate) and Excel (Microsoft). Ribbon counts were performed in the $5-6 \mathrm{kHz}$ region. Tonotopic position was estimated by converting distance from the apex into an approximation of percentage length along the cochlear extent and applying that percentage to previously published mouse frequency maps (Ding et al., 2001; Viberg and Canlon, 2004). Ribbon analysis was performed on 31 cells from three animals at 1 month, 40 cells from four animals at 8.5-9.5 months, and 30 cells from three animals at 11-12 months. Outer hair cell (OHC) counts were performed in the same tissues.

Auditory brainstem response. Mice were anesthetized by intraperitoneal injection of $100 \mathrm{mg} / \mathrm{kg}$ ketamine and $20 \mathrm{mg} / \mathrm{kg}$ xylazine dissolved in $14 \% \mathrm{EtOH}$ and then placed inside a small sound-attenuating chamber 30 $\mathrm{cm}$ from two speakers. Mice were maintained at $37^{\circ} \mathrm{C}$ using a heating pad. Recordings were obtained by placing electrodes over the left bulla and vertex of the skull. A ground electrode was inserted into the leg muscle. Pure tone stimuli were presented for $5 \mathrm{~ms}$ during stimulus pre- sentation, and auditory brainstem response (ABR) measures were controlled and collected using custom MATLAB (MathWorks) software. Stimuli were played through a pair of SuperTweeter speakers (Radio Shack). ABRs were averaged over 300-500 stimulus presentations and bandpass filtered between 300 and $3000 \mathrm{~Hz}$. Threshold was defined as the sound level at which the ABR magnitude was 2 SDs above the average background noise level. Thresholds were determined for four animals at 1 month, four animals at 8.5-9.5 months, and five animals at 11-12 months of age.

Reagents. Curare, strychnine, ACV1, and apamin were acquired from Tocris Bioscience. C-terminal-binding protein 2 (CTBP2) antibody (ribbon labeling) was acquired from Santa Cruz Biotechnology, and Myosin 7A antibody (hair cell labeling) was acquired from the Developmental Studies Hybridoma Bank (University of Iowa).

\section{Results}

Postsynaptic currents were observed in all P7-P10 IHCs when 40 mM external potassium was used to depolarize efferent terminals and were not found in the 1-month-old IHCs (Fig. $1 A, B$ ). However, at $8.5-9.5$ months, $\sim 20 \%$ of IHCs had postsynaptic currents, and this proportion increased to $50 \%$ at $11-12$ months (Fig. $1 A, B$ ). Along with the proportion of apical IHCs innervated at these two ages, the frequency of postsynaptic events also increased from $0.06 \pm 0.02 \mathrm{~Hz}$ at $8.5-9.5$ months to $0.5 \pm 0.14 \mathrm{~Hz}$ at 11-12 months (Fig. 1C).

These recordings were from apical cochlear tissue, corresponding to $\sim 4-10 \mathrm{kHz}$ along the tonotopic axis. To assess cochlear function within this region, we characterized hearing thresholds at $8 \mathrm{kHz}$ for 1-, 8.5- to 9.5-, and 11- to 12-month-old animals by performing $\mathrm{ABR}$ recordings (Fig. $1 D$ ). Relative to 1 month of age, there was an $\sim 16 \mathrm{~dB}$ threshold shift at $8.5-9.5$ months old and an $\sim 50 \mathrm{~dB}$ threshold shift at 11-12 months old. Thus, efferent IHC innervation in the apex and low-frequency hearing thresholds increased in parallel.

To assess anatomical changes at the same ages, we quantified the loss of OHCs and afferent contacts from IHCs in the cochlear apex. Because there is a 1:1 relationship between presynaptic ribbons and the dendrites of spiral ganglion neurons (SGNs), ribbon quantification is a reliable assay of afferent innervation during the aging process (Sergeyenko et al., 2013). We quantified ribbon survival via CTBP2 immunoreactivity in whole-mounted apical turns and observed $\sim 37 \%$ ribbon loss by $8.5-9.5$ months and $\sim 55 \%$ ribbon loss by $11-12$ months (relative to that of 1-monthold animals; Fig. 1E). OHC counts, via Myosin 7A immunoreactivity, in these same tissues also showed a reduction with aging, although to a lesser extent than for ribbon loss (Fig. 1F). The known pattern of degeneration in this mouse broadly follows a basal-to-apical trajectory, similar to that of human cochlear pathology; thus, cytological changes would be still greater in basal regions.

Because $\alpha 9 / 10$ nAChRs have overlapping pharmacology with glycine and GABA receptors that form chloride channels (Rothlin et al., 1999), we performed an experiment to distinguish cationic and anionic postsynaptic currents based on their relative driving force. Efferent transmitter release was evoked with $80 \mathrm{mM}$ external potassium while recording from aged IHCs using an internal (pipette) solution that set $E_{\mathrm{Cl}}$ at $-132 \mathrm{mV}$. Because the hair cells were held at $-80 \mathrm{mV}$, chloride flux would produce an outward current under these conditions. However, only inward postsynaptic currents were observed, indicating that efferent transmitter release does not activate a chloride conductance (Fig. $2 A)$. The receptor mediating these synaptic currents was then characterized using several diagnostic antagonists. Curare at 1 $\mu \mathrm{M}$ reversibly blocked postsynaptic activity, indicating that effer- 


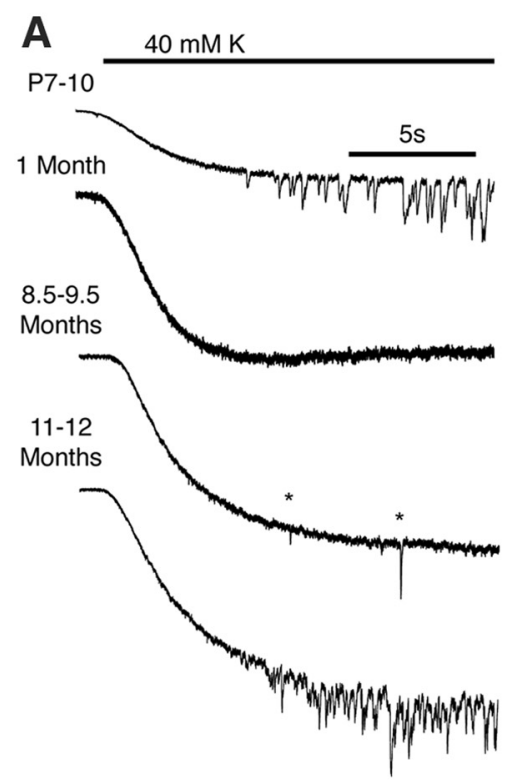

D $8 \mathrm{kHz}$ ABR threshold (dB SPL)

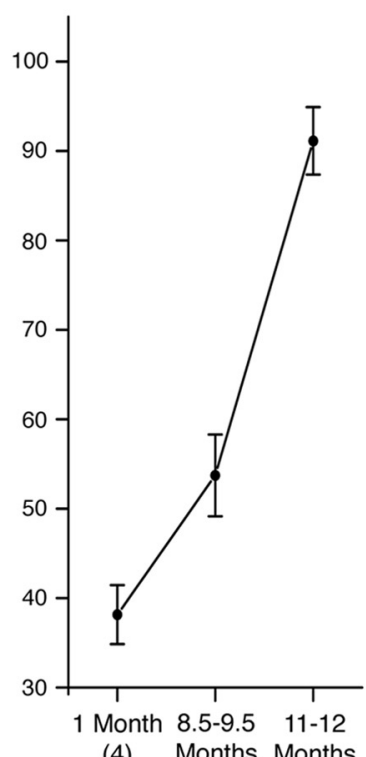

(4)

(5)

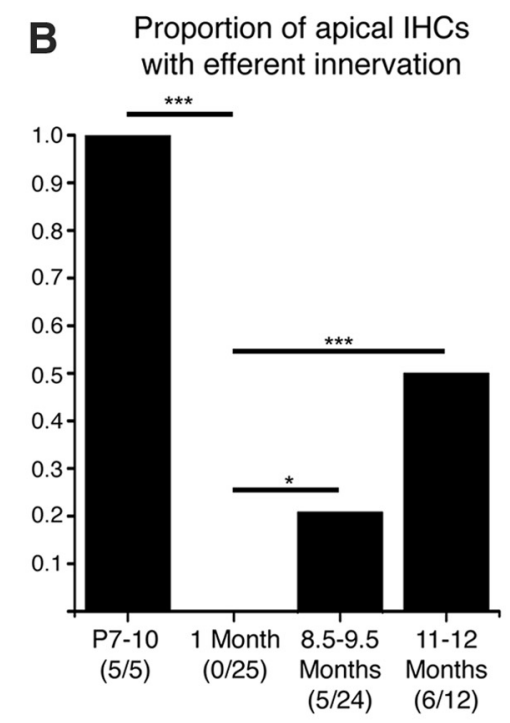

E Ribbon survival (\%)

$\mathbf{F}$

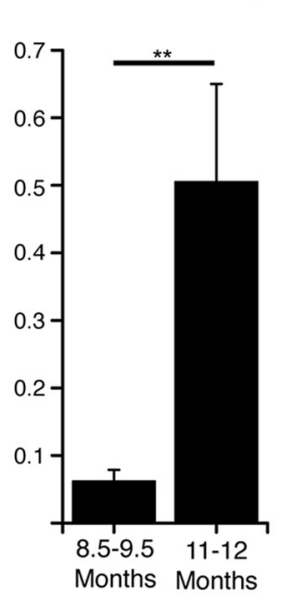

Efferent

release rate $(\mathrm{Hz})$

Figure 1. Efferent innervation returns to IHCs during ARHL. A, Examples of IHC membrane current responses evoked by 40 mm external K at P7-P10, 1 month, 8.5-9.5 months, and 11-12 months. Two synaptic events are marked with asterisks at 8.5 months. $\boldsymbol{B}$, For the same ages, the proportion of apical IHCs with efferent activity in $40 \mathrm{~mm} \mathrm{K.} \boldsymbol{C}$, Efferent release rates increase from 8.5-9.5 to 11-12 months of age. Data are means \pm SEM of the first 10 release events across all recordings in $40 \mathrm{~mm}$ K. D. Hearing thresholds at $8 \mathrm{kHz}$ were determined for 1-, 8.5- to 9.5-, and 11to 12-month-old animals by ABR recordings. Means \pm SEMs: $38.15 \pm 3.29,53.72 \pm 4.58$, and $91.14 \pm 3.78$. $\boldsymbol{E}$, $\boldsymbol{F}$, Ribbon and OHC survival at $8.5-9.5$ and $11-12$ months of age expressed as a percentage of each measurement at 1 month of age. Mean \pm SEM ribbon values per IHC: $10.1 \pm 0.22,6.3 \pm 0.36$, and $4.5 \pm 0.32$. $0 \mathrm{HCs}$ were quantified across a $200 \mu \mathrm{m}$ distance in the same region. Mean \pm SEM OHC values: $73 \pm 1.15,62.25 \pm 1.03$, and $55.33 \pm 4.33 .{ }^{*} p<0.05,{ }^{* *} p<0.01,{ }^{* * *} p<0.001$

ents contacting aged IHCs are cholinergic (Fig. 2B). Strychnine, a potent antagonist of $\alpha 9 / 10$ receptors (Rothlin et al., 1999), also blocked activity reversibly at $1 \mu \mathrm{M}$, as did the $\alpha 9$-specific toxin ACV1 (Vincler et al., 2006) at $500 \mathrm{~nm}$ (Fig. 2C,D). These data indicate that, as for early postnatal IHCs, aged IHCs are contacted by cholinergic efferents that activate $\alpha 9$-containing nAChRs.

Local application of ACh to aged IHCs held at $-80 \mathrm{mV}\left(E_{\mathrm{K}}\right)$ induced inward current, presumably through nAChRs (Fig. $3 A$ ). However, when ACh was applied to cells held at $-40 \mathrm{mV}$, the ACh-induced current was outward. Thus, nAChRs are function- ally coupled to potassium channels in aged IHCs, making efferent transmission inhibitory as in immature IHCs. The mean reversal potential for the ACh-induced current was $-68.71 \pm 0.4 \mathrm{mV}$ (Fig. 3B). To determine the specific subtype of potassium channel that mediates the inhibitory component, we recorded inward synaptic currents in $80 \mathrm{~mm}$ external potassium and then applied $400 \mathrm{~nm}$ apamin, a specific antagonist for small-conductance, calcium-activated SK channels. As is the case for immature efferent postsynaptic currents (Oliver et al., 2000; Gómez-Casati et al., 2005; Rohmann et al., 2015), apamin reduced the time constant of decay of the synaptic currents (from $35.88 \pm 2.01$ to $13.34 \pm$ 
A

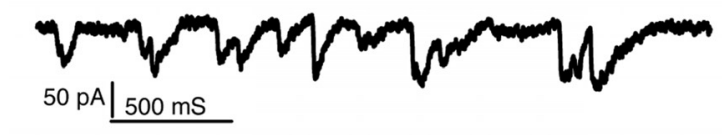

B

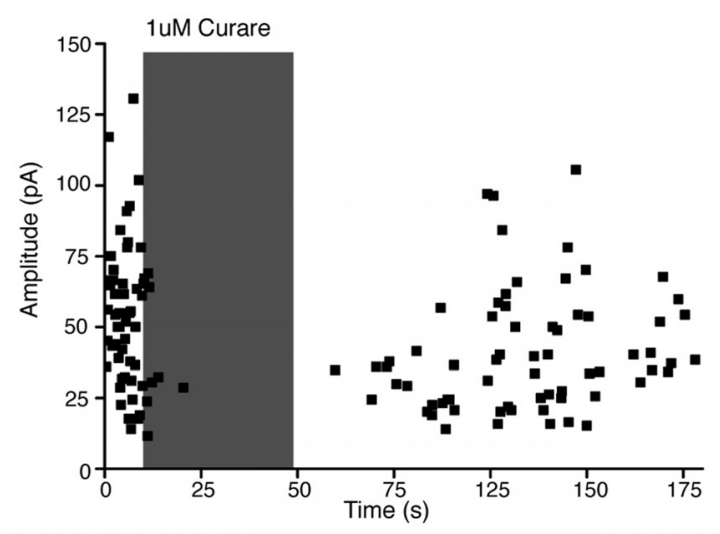

C

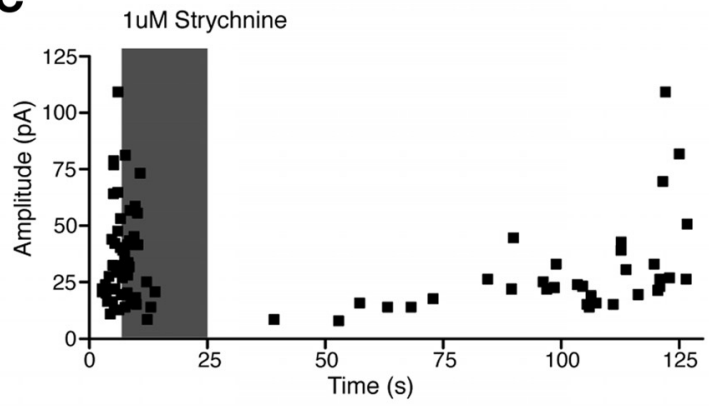

D

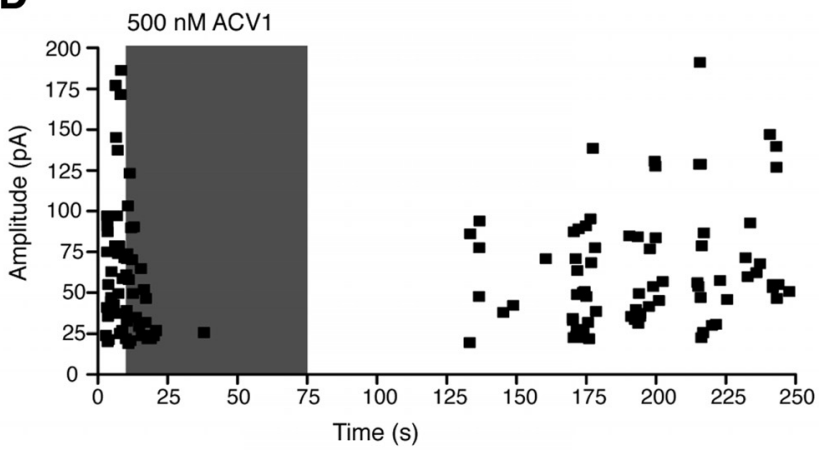

Figure 2. Efferents contacting aged IHCs are cholinergic and activate $\alpha 9$-containing receptors. $\boldsymbol{A}-\boldsymbol{D}$, Eleven- to 16 -month-old IHCs, efferent transmitter release induced by $80 \mathrm{~mm} \mathrm{~K}$, cells voltage clamped at $-80 \mathrm{mV}$. $A$, Inward currents indicate that efferents contacting aged IHCs do not open $\mathrm{Cl}$ channels because those currents would be outward. $E_{\mathrm{Cl}}$ of $-132 \mathrm{mV}$ ( $n=2$ cells). $\boldsymbol{B}-\boldsymbol{D}$, Cells voltage clamped at $E_{C \mid}$ of $-80 \mathrm{mV}$. $\boldsymbol{B}$, Diary plot of postsynaptic current amplitudes over time for a single cell. Curare at $1 \mu \mathrm{m}$ blocked synaptic activity $(n=4)$. C, Strychnine at $1 \mu \mathrm{m}$ blocked synaptic activity $(n=2)$. D, ACV1 at 500 nm blocked synaptic activity $(n=2)$.

$0.81 \mathrm{~ms}$ ), indicating that SK channels are involved in the synaptic response to ACh. Apamin also reduced the mean amplitude (from $70.62 \pm 4.0$ to $46.23 \pm 2.0 \mathrm{pA}$ ), as expected from the large inward driving force on potassium in these conditions.

\section{Discussion}

We have recorded from IHCs in the cochlear epithelium of aged C57 mice and provide a physiological characterization of synaptic reorganization that accompanies ARHL. A single nucleotide
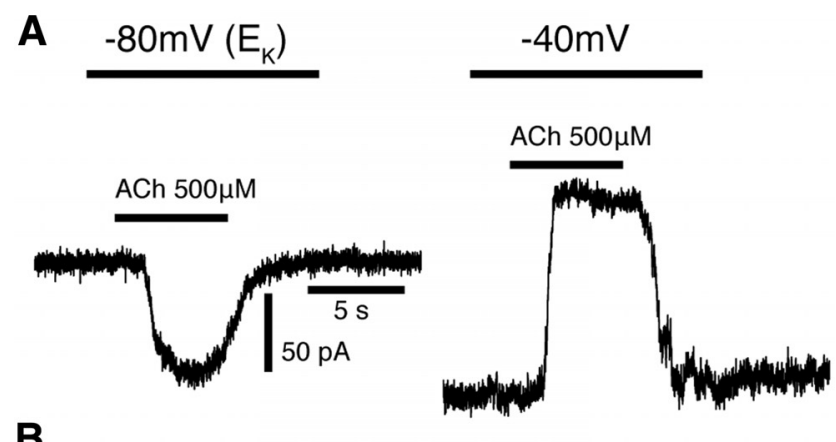

B
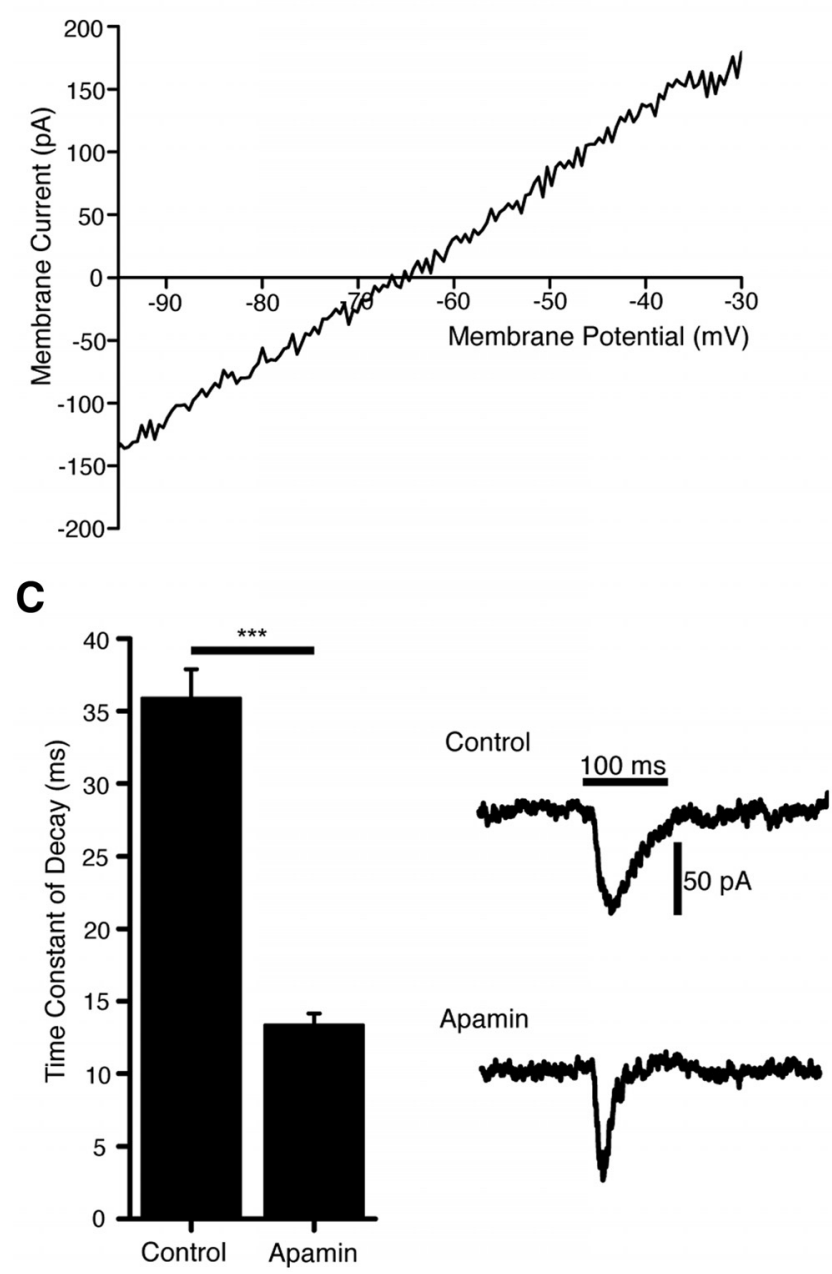

Figure 3. Efferents contacting aged IHCs activate SK channels. $A$, Membrane current responses to local application of ACh at $-80 \mathrm{mV}$ (left) and $-40 \mathrm{mV}$ (right). $\boldsymbol{B}$, Example I-V relationship of the ACh-induced current. Mean \pm SEM reversal potential was $-68.71 \pm 0.4$ $\mathrm{mV}$ ( $n=5$ cell; 2 cells at $11-12$ months, 2 cells at $13-14$ months, and 1 cell at $14-15$ months). C, Apamin at $400 \mathrm{~nm}$ reduced the time constant of decay for inward synaptic currents recorded in $80 \mathrm{~mm}$ external $\mathrm{K}\left({ }^{* * *} p<0.001, n=67\right.$ events across 2 recordings, 14 - to 15 -month-old cells).

polymorphism in cadherin 23 (Cdh23) is thought to underlie the progressive hearing loss characteristic of the C57 mouse (Johnson et al., 1997, Noben-Trauth et al., 2003), raising the possibility that IHC reinnervation is somehow consequent to this mutation. The Cdh23 protein acts as a component of tip links and thus is important for transduction (Siemens et al., 2004), but synaptic structures and the peripheral innervation patterns are normal in the immature and young adult C57 mouse. Additionally, electron microscopy in the guinea pig cochlea after AMPA administration 
through the round window also reveals re-emergent efferent IHC synapses, suggesting that efferent innervation of IHCs may be a common feature of the damaged mammalian cochlea (Ruel et al., 2007). Additional physiological studies, across mouse lines and species, are necessary to describe the extent to which this innervation pattern arises during pathology.

The cholinergic synapses on aged IHCs demonstrate the same ionic mechanisms involved in transient efferent inhibition of IHCs before hearing onset. In both of these epochs, there is an apparent reciprocity between efferent and afferent innervation, suggesting that competition for territory or another form of crosstalk regulates these neuronal contacts. The re-emergent efferent synapses on IHCs could arise from medial or lateral olivocochlear efferents. Medial efferents, which contact OHCs in the adult, may reactively sprout after $\mathrm{OHC}$ or afferent loss to recapitulate the IHC synapses they made during early postnatal development. During the aging process, medial efferent terminals below OHCs can be lost even when OHCs themselves remain intact (Fu et al., 2010). Lateral efferents contact nearby afferent dendrites and so are perhaps better positioned to move onto IHCs during afferent denervation. The greater proportional loss of IHC ribbons (afferents) than of OHCs (Fig. 1E,F) may argue in favor of lateral efferents as the source of these IHC synapses. If so, this implies that lateral efferents can form cisternal synapses on hair cells, as well as their usual contacts with afferent dendrites.

Whatever their origin, efferent synapses on aged IHCs include the near-membrane postsynaptic cistern (Smith and Sjöstrand, 1961; Saito, 1980; Lauer et al., 2012) that serves to segregate synaptic calcium signals (Sridhar et al., 1997; Lioudyno et al., 2004; Im et al., 2014). Postsynaptic cisterns also are a feature of cholinergic contacts ("C-terminals") on spinal motor neurons (Nagy et al., 1993), in which they have been shown to enlarge with afferent denervation (Pullen and Sears, 1978) and in upper motor neuron disease (Pullen and Athanasiou, 2009). It has been proposed that "C-terminal" expansion may be an adaptation to compensate for loss of excitatory inputs.

Although the present work provides parallels with " $\mathrm{C}$ terminal" innervation of central neurons, efferent reinnervation of IHCs is clearly not for excitatory compensation. Rather, efferent inhibition of IHCs is more likely to contribute to the progression of hearing impairment via suppression of afferent outflow. This widespread inhibition becomes relevant in the context of tinnitus to the extent that reduced cochlear signaling is thought to give rise to pathological central plasticity (Dong et al., 2010). It will be of interest to learn whether efferent feedback shapes afferent activity as during development and thereby influences central synaptic organization. In terms of the organization of the IHC synaptic complex, efferent synapses may physically prevent afferent dendrites from reclaiming synaptic territory on the IHC after acute denervation. Conversely, SGNs are susceptible to excitotoxic damage and death (Pujol and Puel, 1999; Kujawa and Liberman, 2009), and efferent inhibition may protect them by reducing IHC glutamate release in loud environments.

Inhibitory efferent IHC synapse formation is contemporaneous with afferent synaptic loss, OHC death, and decreased acoustic sensitivity. Our understanding of olivocochlear efferent function during development, in healthy adulthood, and into old age is incomplete. Whether efferent activity exacerbates hearing loss, protects SGNs from excitotoxicity, or serves another role is unclear; nevertheless, our work establishes the possibility that efferent IHC synapses are a feature of hearing loss and associated pathologies.

\section{References}

Clause A, Kim G, Sonntag M, Weisz CJ, Vetter DE, Rúbsamen R, Kandler K (2014) The precise temporal pattern of prehearing spontaneous activity is necessary for tonotopic map refinement. Neuron 82:822-835. CrossRef Medline

Ding D, McFadden SL, Salvi RJ (2001) Cochlear cell densities and inner ear staining techniques. In: Handbook of mouse auditory research (Willott JF, ed), pp 189-204. Boca Raton, FL: CRC.

Dong S, Mulders WH, Rodger J, Woo S, Robertson D (2010) Acoustic trauma evokes hyperactivity and changes in gene expression in guinea-pig auditory brainstem. Eur J Neurosci 31:1616-1628. CrossRef Medline

Elgoyhen AB, Johnson DS, Boulter J, Vetter DE, Heinemann S (1994) Alpha 9: an acetylcholine receptor with novel pharmacological properties expressed in rat cochlear hair cells. Cell 79:705-715. CrossRef Medline

Fu B, Le Prell C, Simmons D, Lei D, Schrader A, Chen AB, Bao J (2010) Age-related synaptic loss of the medial olivocochlear efferent innervation. Mol Neurodegener 5:53. CrossRef Medline

Glowatzki E, Fuchs PA (2000) Cholinergic synaptic inhibition of inner hair cells in the neonatal mammalian cochlea. Science 288:2366-2368. CrossRef Medline

Gómez-Casati ME, Fuchs PA, Elgoyhen AB, Katz E (2005) Biophysical and pharmacological characterization of nicotinic cholinergic receptors in rat cochlear inner hair cells. J Physiol 566:103-118. CrossRef Medline

Im GJ, Moskowitz HS, Lehar M, Hiel H, Fuchs PA (2014) Synaptic calcium regulation in hair cells of the chicken basilar papilla. J Neurosci 34:1668816697. CrossRef Medline

Johnson KR, Erway LC, Cook SA, Willott JF, Zheng QY (1997) A major gene affecting age-related hearing loss in C57BL/6J mice. Hear Res 144:83-92. Medline

Johnson SL, Eckrich T, Kuhn S, Zampini V, Franz C, Ranatunga KM, Roberts TP, Masetto S, Knipper M, Kros CJ, Marcotti W (2011) Positiondependent patterning of spontaneous action potentials in immature cochlear inner hair cells. Nat Neurosci 14:711-717. CrossRef Medline

Katz E, Elgoyhen AB, Gómez-Casati ME, Knipper M, Vetter DE, Fuchs PA, Glowatzki E (2004) Developmental regulation of nicotinic synapses on cochlear inner hair cells. J Neurosci 24:7814-7820. CrossRef Medline

Kujawa SG, Liberman MC (2009) Adding insult to injury: cochlear nerve degeneration after "temporary" noise-induced hearing loss. J Neurosci 45:14077-14085. CrossRef Medline

Lauer AM, Fuchs PA, Ryugo DK, Francis HW (2012) Efferent synapses return to inner hair cells in the aging cochlea. Neurobiol Aging 33:28922902. CrossRef Medline

Lioudyno M, Hiel H, Kong JH, Katz E, Waldman E, Parameshwaran-Iyer S, Glowatzki E, Fuchs PA (2004) A "synaptoplasmic cistern" mediates rapid inhibition of cochlear hair cells. J Neurosci 24:11160-11164. CrossRef Medline

Morley BJ, Simmons DD (2002) Developmental mRNA expression of the alpha10 nicotinic acetylcholine receptor subunit in the rat cochlea. Brain Res Dev Brain Res 139:87-96. CrossRef Medline

Nagy JI, Yamamoto T, Jordan LM (1993) Evidence for the cholinergic nature of C-terminals associated with subsurface cisterns in alphamotoneurons of rat. Synapse 15:17-32. CrossRef Medline

Noben-Trauth K, Zheng QY, Johnson KR (2003) Association of cadherin 23 with polygenic inheritance and genetic modification of sensorineural hearing loss. Nat Genet 35:21-23. CrossRef Medline

Oliver D, Klöcker N, Schuck J, Baukrowitz T, Ruppersberg JP, Fakler B (2000) Gating of Ca2+-activated K+ channels controls fast inhibitory synaptic transmission at auditory outer hair cells. Neuron 26:595-601. CrossRef Medline

Pujol R, Puel JL (1999) Excitotoxicity, synaptic repair, and functional recovery in the mammalian cochlea: a review of recent findings. Ann NY Acad Sci 28:249-254. CrossRef Medline

Pullen AH, Athanasiou D (2009) Increase in presynaptic territory of C-terminals on lumbar motoneurons of G93A SOD1 mice during disease progression. Eur J Neurosci 29:551-561. CrossRef Medline

Pullen AH, Sears TA (1978) Modification of "C" synapses following partial central deafferentation of thoracic motoneurones. Brain Res 145:141146. CrossRef Medline

Rohmann KN, Wersinger E, Braude JP, Pyott SJ, Fuchs PA (2015) Activation of BK and SK channels by efferent synapses on outer hair cells in high 
frequency regions of the rodent cochlea. J Neurosci 35:1821-1830. CrossRef Medline

Rothlin CV, Katz E, Verbitsky M, Elgoyhen AB (1999) The alpha9 nicotinic acetylcholine receptor shares pharmacological properties with type A gamma-aminobutyric acid, glycine, and type 3 serotonin receptors. Mol Pharmacol 55:248-254. Medline

Roux I, Wersinger E, McIntosh JM, Fuchs PA, Glowatzki E (2011) Onset of cholinergic efferent synaptic function in sensory hair cells of the rat cochlea. J Neurosci 31:15092-15101. CrossRef Medline

Ruel J, Wang J, Rebillard G, Eybalin M, Lloyd R, Pujol R, Puel JL (2007) Physiology, pharmacology and plasticity at the inner hair cell synaptic complex. Hear Res 227:19-27. CrossRef Medline

Saito K (1980) Fine structure of the sensory epithelium of the guinea pig organ of Corti: afferent and efferent synapses of hair cells. J Ultrastruct Res 71:222-232. CrossRef Medline

Sendin G, Bourien J, Rassendren F, Puel JL, Nouvian R (2014) Spatiotemporal pattern of action potential firing in developing inner hair cells of the mouse cochlea. Proc Natl Acad Sci U S A 5:1999-2004. CrossRef Medline

Sergeyenko Y, Lall K, Liberman MC, Kujawa SG (2013) Age-related co- chlear synaptopathy: an early-onset contributor to auditory functional decline. J Neurosci 33:13686-13694. CrossRef Medline

Siemens J, Lillo C, Dumont RA, Reynolds A, Williams D, Gillespie PG, Müller U (2004) Cadherin 23 is a component of the tip link in hair cell stereocilia. Nature 428:950-955. CrossRef Medline

Simmons DD (2002) Development of the inner ear efferent system across vertebrate species. J Neurobiol 53:228-250. CrossRef Medline

Smith CA, Sjöstrand FS (1961) Structure of the nerve endings on the external hair cells of the guinea pig cochlea as studied by serial sections. J Ultrastruct Res 5:523-556. CrossRef Medline

Sridhar TS, Brown MC, Sewell WF (1997) Unique postsynaptic signaling at the hair cell efferent synapse permits calcium to evoke changes on two time scales. J Neurosci 17:428-437. Medline

Viberg A, Canlon B (2004) The guide to plotting a cochleogram. Hear Res 197:1-10. CrossRef Medline

Vincler M, Wittenauer S, Parker R, Ellison M, Olivera BM, McIntosh JM (2006) Molecular mechanisms for analgesia involving specific antagonism of alpha9 alpha10 nicotinic acetylcholine receptors. Proc Natl Acad Sci U S A 103:17880-17884. CrossRef Medline 